LETTER

\section{Further thoughts on limitations, uncertainties and competing interpretations regarding chemical exposures and diabetes}

Although disappointed, we are not surprised that Trasande's response tries to avoid a serious discussion of legitimate scientific issues by accusing those who disagree with him of being unduly influenced by industry.

One could easily counter that the authors appear to suffer from 'white hat bias', defined ${ }^{12}$ as 'bias leading to distortion of information in the service of what may be perceived as righteous ends'.

A consistent theme in the Trasande et al response to our letter is that scientists dedicated to factual and provable scientific facts are 'manufacturing doubt'. Their obvious intention is to intimidate and quash legitimate scientific discussion. Irrespective of the latter, doubt in scientific enquiry is constructive, no matter how challenged one may feel by it.

As even Trasande et al acknowledge, our criticisms were also cited by the authors of the original Prospective Investigation of the Vasculature in Uppsala Seniors studies and remain valid in the subject derivative paper. We maintain that a discussion of the criticisms should have been added into that paper to facilitate readers forming their own assessment of the results, conclusions and health implications.

Contrary to the assertion by Trasande et al, we have not dismissed the existing epidemiological literature on this topic, but merely pointed out that there are other groups who have reviewed and assessed that same literature and found it wanting in various respects. Those reviewers also found fault with the in vivo and in vitro data on glucose tolerance and consequently recommended additional studies. Trasande et al should have acknowledged these viewpoints.

We are encouraged that Trasande et al concur with our view that more robust longitudinal studies are needed, although true science demands maintaining an open mind about the outcomes and any potential influence on future cost estimates.

The remainder of the response from Trasande et al is a commercial for other dubious cost estimates generated by Trasande and collaborators. We did not comment on those cost estimates because they were beyond the scope of the subject paper which focused on obesity and diabetes. However, others ${ }^{3-5}$ have questioned the assumptions made and results obtained therein, so we would caution caveat emptor.

Accordingly, we are concerned at the overt display of incongruence by Trasande et al, that is, publishing questionable science while claiming their science to be the foundation for questioning current and well-proven approaches for human health protection.

\section{Gregory G Bond, ${ }^{1}$ Daniel R Dietrich ${ }^{2}$}

${ }^{1}$ Manitou View Consulting LLC, Northport, Michigan, USA

${ }^{2}$ Department of Human and Environmental Toxicology, University of Konstanz, Konstanz, Germany

Correspondence to Dr Gregory G Bond, 8797 N. Gills Pier Rd, Northport, Ml 49670, USA; gregory.g.bond@ gmail.com

Contributors Both authors have contributed equally to the writing of this manuscript.

Competing interests GGB provides consulting services to the American Chemistry Council which represents more than 160 leading companies engaged in the business of chemistry. DD declares no competing interests.

Provenance and peer review Not commissioned; internally peer reviewed.
Open Access This is an Open Access article distributed in accordance with the Creative Commons Attribution Non Commercial (CC BY-NC 4.0) license, which permits others to distribute, remix, adapt, build upon this work non-commercially, and license their derivative works on different terms, provided the original work is properly cited and the use is noncommercial. See: http://creativecommons.org/licenses/ by-nc/4.0/

(C) Article author(s) (or their employer(s) unless otherwise stated in the text of the article) 2017. Al rights reserved. No commercial use is permitted unless otherwise expressly granted.

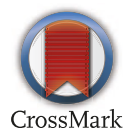

To cite Bond GG, Dietrich DR. J Epidemiol Community Health 2017;71:943

Received 12 May 2017

Accepted 20 May 2017

Published Online First 8 July 2017

J Epidemiol Community Health 2017:71:943 doi:10.1136/jech-2017-209451

\section{REFERENCES}

1 Cope MB, Allison DB. White hat bias: examples of its presence in obesity research and a call for renewed commitment to faithfulness in research reporting. Int $\mathrm{J}$ Obes 2010:34:84-8.

2 Atkinson RL, Macdonald I. White hat bias: The need for authors to have the spin stop with them. Int J Obes 2010;34:83

3 Middelbeek RJ Veuger SA Letter to the Editor: Re: Neurobehavioral Deficits, Diseases, and Associated Costs of Exposure to Endocrine-Disrupting Chemicals in the European Union. J Clin Endocrinol Metab 2015:100:L52-3.

4 European Commission. Staff Working Document: defining criteria for identifying endocrine disruptors in the context of the implementation of the plant protection products regulation and biocidal products regulation, 2016. See page 27. http://ec.europa.eu/ health/endocrine_disruptors/docs/2016_impact_ assessment en.pdf.

5 Bonde JP, Flachs EM, Rimborg $S$, et al. The epidemiologic evidence linking prenatal and postnatal exposure to endocrine disrupting chemicals with male reproductiv disorders: a systematic review and meta-analysis. Hum Reprod Update 2016;23:104-25 https://doi.org/. 